\title{
Introduction
}

\section{Better Britains?: Settler Societies Within the British Empire 1783-1920}

The spread, persistence, and effects of empires, as well as their lingering presence in today's world, have become a major preoccupation for scholars in the early twenty-first-century academy. Historians, literary specialists, cultural theorists, anthropologists, and geographers (to name practitioners of a few prominent disciplines) have drawn our attention to the ways in which imperial powers reshaped the lives and landscapes of millions of people around the world, both those who became subject to imperial rule and those who were, in various ways, imperial rulers. While the study of imperial expansion and imperial encounters is chronologically wide-ranging and takes in multiple forms of empire, the nineteenth century and, in particular, the expansion of British imperial power around the world during that time have been the focus of a diverse body of scholarship. Although the reasons for scholars' fascination with nineteenth-century British imperial history are multiple and complex, one key factor for the great volume of work in this area can be traced to the rapidity and range of British imperial expansion over this period. Over the course of the nineteenth century, Britain acquired Io million square miles - a territory that included 400 million people, making it the largest of Europe's imperial powers. It also created a range of colonies and protectorates, ones that encompassed direct governance (the Caribbean, Hong Kong, and, by I858, India), rule through military occupation (Egypt), and settler colonialism. This book explores the latter subject, examining the spread of settler colonies within the British Empire over the course of the nineteenth century. 
Settler colonialism was not a phenomenon limited to the British Empire, of course. Other imperial powers also created colonies in which the formation of new, long-lasting societies for colonists, effected through the dispossession and dispersal of Indigenous peoples, occurred alongside the extraction of resources for the metropole. British settler colonialism, though, was particularly persistent, pervasive, and long-lasting. British settlers also spread outside the boundaries of those colonies that are the subject of this book-Australia, Canada, New Zealand, and South Africa - to places such as Argentina and, of course, the United States, developments that have been explored by historians James Belich and John Weaver. Moreover, settler colonialism was related to the British Empire's global expansion. It took place in a context of other forms of British colonialism and shared a number of features: a range of social, political, cultural, and economic connections to the metropole; a belief in the supremacy of "British" values and institutions; and a willingness to resort to military violence, simultaneously coupled with a staunch faith in the benevolence and humanitarianism of the British Empire. Furthermore, British settler colonies were, like other British colonies, structured by a number of hierarchies. Relationships of race, gender, class, and religion were critical in determining categories of inclusion and exclusion. Who would be considered a "British subject" and in what particular ways would they be seen as such by settlers and various levels of government were processes that were, as in other colonial settings, shaped by relations of power and dominance. These hierarchies might be mutable and were subject to challenges from various groups, both within the colonies themselves and the metropole. Nonetheless, they helped shape these societies and gave them their form and structure.

Yet we can also identity a range of significant differences that, over time, came to distinguish British settler colonialism from the forms of imperial expansion that occurred in other colonies. One of the most critical and important distinctions that shaped settler colonialism was the assumption that the British settlers' presence would be permanent, an expectation that had significant and enduring implications for Indigenous people. Demographics also played an important role in British settler colonies. With the exception of South Africa, white settlers came to outnumber Indigenous people over the course of the nineteenth century. This development had serious political, social, and cultural implications for both colonized and colonizer, a theme that runs through various chapters of this book. While this book explores the ongoing ties between Britain and her settler colonies, it also points to the growth of settler nationalism and demands for a distinct 
and differentiated status within the Empire, most notably over the question of responsible government.

In addition to differences between settler colonies and colonies whose primary purpose was economic and/or military and diplomatic usefulness to Britain, the societies considered here had their own particular and specific histories. Some had already been affected by European presence and had been marked by warfare between groups of Europeans as well as European-Indigenous conflict. Some negotiated treaties with Indigenous peoples, while others had no formal agreements with the latter. While they all were connected to Britain, their relationships with the metropole were shaped by a range of dynamics, not least metropolitan attitudes concerning these colonies' military, diplomatic, and economic potential and usefulness for imperial goals, attitudes which shifted over time. Moreover, while these colonies were part of a network of "British worlds," those links and connections of people, goods, practices, institutions, and identities that tied them to the metropole (and at times to each other), their histories were affected by other worlds and other sets of networks. Australia and New Zealand, for example, were tied to Pacific routes of trade and migration; by the early twentieth century Australia, in particular, also looked to the United States. Canada had links to Atlantic, Pacific, and Caribbean networks, and it was also connected to the United States. In turn, while South Africa's Cape Colony and Natal were tied to Britain through markets, missionaries, and the military, they also were linked to an Indian Ocean world of migration and labour. Settler societies' constitution over the nineteenth century is best explored, I argue, from multiple perspectives - not least those of settler colonists themselves - so that we can appreciate the dynamic interplay between them and the wider worlds to which they were linked. This dynamism was a significant part of their histories.

Building Better Britains? opens in 1783 and spans the nineteenth and early twentieth centuries, ending in the aftermath of World War I. The American Revolution (1776-83) and the Napoleonic Wars (1803-15) were pivotal moments in the founding of these colonies. In a similar vein, the early I920S saw significant developments in settler nationalism. Such identities had been shaped by both the South African War (I899-1902) and World War I; the commemoration of these events was marked by both an ongoing connection to Britain and a sense of settler societies' individual contributions to these conflicts. As well, the networks and connections between these societies and Britain that developed over the course of the nineteenth century did not end in I919. Indeed, in the aftermath of World War I emigration 
from Britain to settler societies continued to occur at relatively high levels. By I93 I, though, these colonies had become, for the most part, Dominions. Their twentieth-century histories are sufficiently complex and multilayered to warrant their own treatment.

Chapter I explores colonial relationships with Indigenous peoples. A central, defining feature of these colonies was their relationship with their original inhabitants. Indigenous-newcomer contacts involved conflict, negotiation, and - at times - cooperation over land, resources, political governance, intimate relations, and cultural representations. These developments were not one-sided, predictable, or homogeneous. Depending on time and location, they resulted in treaties, formal warfare, informal physical conflict, or some combination of all three. In some contexts, such as Australia or Canada's Pacific coast, treaties were more pronounced by their absence. These relationships were also mediated by factors such as colonists' need for Indigenous peoples' trading networks and knowledge of geography, climate, and topography. Preexisting relationships, whether forged through military alliances and conflicts, trade, or missionary work, also affected nineteenth-century developments. Yet while the Indigenous societies that settlers encountered were marked by their heterogeneity, over the course of the nineteenth century a common theme in settler colonies' history was Indigenous peoples' increased marginalization. They lost more control of land and resources, increasingly inhabited designated areas controlled by colonial officials, saw their physical mobility limited by legislation and practice, and experienced the suppression of their languages and culture. (Simultaneously, Indigenous culture frequently was appropriated by settler civil society as a way of distinguishing its culture from that of the metropole.) Indigenous people reacted to these developments in a number of ways: armed and open resistance, such as the New Zealand Wars (I845-72) or the Cape Colony's I85I Kat River Uprising; negotiation and cooperation, which might involve intermarriage with settlers, becoming members of missionary societies, or fighting for colonial powers; or engaging in Indigenous revivals of language and culture, thus drawing boundaries (as best they could) between themselves and settlers.

Chapter 2 explores the processes of migration and settlement in these colonies, ones that began in the late eighteenth century and intensified after the end of the Napoleonic Wars. Waves of British, other European, and-in some contexts-African people found their way to the Antipodes, British North America, and the Cape Colony. This migration took a number of forms. It might be forced, as in the case of convict transportation to New 
South Wales; it might be the movement of refugees fleeing the aftermath of the American Revolution; or it might be that of men and women who sought better futures as a result of social and economic upheaval in Britain. The chapter also examines the implementation of structures of governance in settler colonies, as they shared British law and legal systems, not to mention colonial governors. The latter, along with members of the judiciary, both travelled from Britain to the colonies and moved between colonial sites. However, while by the end of the nineteenth century settler colonies shared much in their legal structures and methods of policing, these developments also were influenced by local conditions and particular historical contingencies. Questions that surrounded political representation, particularly challenges to the authority of colonial governors and the issue of "responsible government," also became urgent and important to settlers during the nineteenth century. They were shaped by concepts of liberal democracy and the possibility that settler societies might represent new opportunities for white male settlers. By the middle of the century settlers began to form national governments, processes that were primarily conducted through constitutional negotiations between different provincial bodies, whether in I867 British North America or I90I Australia. The I9Io Union of South Africa, though, was a different matter. It had been preceded by a war that involved Britain and her supporters in the region, the Boer republics, and other settler Dominions.

Settler economies and the labour they depended on are the subject of Chapter 3 . In the late eighteenth and early nineteenth centuries, the imperial state and, to no small extent, the British military were significant actors in shaping settler economies. While the mid-nineteenth century saw the end of mercantilism and the rise of free trade, imperial investments and exchanges within the "British world" were significant, indeed critically important, for the settler societies' economies. By the early twentieth century Australia, British America (Canada), the Cape, and New Zealand were actively engaged in financial networks that intensified their ties to the metropole. Such networks moved credit, technology, and material culture across the British Empire and underpinned the expansion of settler economies. Although the ideal form of settlement for these colonies was that of the small, independent "yeoman" farmer, this model was not achieved in every society or, at least, not in its idealized version. Some contexts, climate, and topography made it far from being feasible. Settler societies' economies were marked not just by agriculture but by pastoralism, whaling, logging, fishing, mining, and, toward the end of the century, 
industrial production. Accordingly, settler economies relied on and mobilized a wide range of labour: that of the household and family; the unfree labour of slaves or convicts; the coerced and unpaid labour of Indigenous people; South Asian indentured labour; and Chinese contract labour. British migrants also brought with them both the belief that labour had the right to organize collectively and their experiences within the British trade union movement. In settler societies, though, the labour movement was shaped by racial, ethnic, and gendered hierarchies.

Chapter 4 then turns to the domain of "civil society": the family, domesticity, and intimate relations; religion; voluntary associations and institutions; and education. Importing British institutions - whether marriage, churches, or schools - was a concern and, in many ways, a struggle for colonial officials and settlers. For one, they brought with them assumptions about heterosexual marriage and the need for patriarchal households as the "building block" of settler society. Yet in the context of places such as Australia or British America, concerns about marriage were also shaped by the question of interracial sexuality and the presence of other kinds of marriages and intimate relations. As well as trying to regulate marriage, colonial elites also attempted to regulate the behaviour of colonists, Indigenous communities, and racialized people through voluntary institutions; edicts about manners and behaviour; and ordinances that governed disease, drinking, and sexual conduct. Through its dissemination of beliefs, people, and artifacts, the British missionary movement played a role in such practices. It also helped link settler societies to the metropole, to each other, and, in many cases, to other British colonies. Moreover, the drive for spiritual self-improvement also had its secular counterpart, in the spread of both institutions that promoted informal types of learning and those of formal, state-supported and organized education. Settler colonists' arguments for compulsory, state-regulated, and free education were inspired by developments both in Britain and in Europe. They also, however, were shaped by the belief that colonists needed education in order to create "better Britains" made up of "better Britons." Such developments were not seamless or untouched by hierarchies of gender, race, and class, at the level of either primary or university education.

Chapter 5 closes the book with an exploration of identity and culture in settler societies. Settler colonists thought of themselves as "British," albeit in multilayered ways and in ways that were informed by conceptions of settler nationalism. Settler constructions of identity took a number of forms: they were expressed in attitudes toward the Crown, forms of cultural 
representation, the press, and concepts of both the future and the past. From the mid-nineteenth century on, settler societies also began to display themselves in industrial and imperial exhibitions. Such displays highlighted themes of agricultural development, the richness of colonial resources, the progress of manufacturing, and the advance of settler "civilization" (in some cases, through the exhibition of "civilized" Indigenous people). Finally, settler societies' participation in war, particularly in South Africa and World War I, also led to the creation of narratives, monuments, prose and poetry, and other forms of representation that valourized the Dominions' participation in such conflicts. These cultural genres suggested that such experiences were not only important testimonies to imperial devotion and loyalty but also part of the process of nation-building. As with many other aspects of settler societies' construction, the creation of such identities was not a neutral process, devoid of relationships of power. For one, it was profoundly gendered. Although white, middle-class women often were keen participants, they were limited to certain images and narratives, usually cast as "mothers of the nation" or represented as allegorical or mythical figures. While at times working-class men and women supported imperial and nationalistic ventures, they often had little or no control over dominant narratives of empire and nation. Racial minorities and Indigenous people were by no means silent in asserting their own identities and distinct cultures and histories. Nevertheless, in general their experiences were overlooked and subsumed, particularly as settler nations became increasingly structured by more restrictive and racially exclusionary policies and practices.

Building Better Britains? explores the shared histories of these societies, while simultaneously being sensitive to the nuances that at times differentiated them from each other. Often seen within national frameworks, the histories of these settler colonies provide us with another means of conceptualizing the multiple ways in which the British Empire reshaped the nineteenth-century world. As we will see in Chapter I, such reshaping had profound effects on the worlds and societies of Indigenous people. 
This page intentionally left blank 